ORIGINAL SCIENTIFIC PAPER

RECEIVED: NOVEMBER 2016

REVISED: FEBRUARY 2017

ACCEPTED: FEBRUARY 2017

DOI: 10.1515/ngoe-2017-0002

UDK: 347.736

JEL: G33, G34

Citation: Zorin Bukovšek, M., Bratina, B., \& Tominc, P. (2017). Factors of a Successfully Implemented Compulsory Settlement. Naše gospodarstvo/Our Economy, 63(1), 14-26. DOI: 10.1515/ ngoe-2017-0002

\section{NG OE}

NAŠE GOSPODARSTVO OUR ECONOMY

\section{Vol. 63 No.1 2017}

pp. $14-26$

\title{
Factors of a Successfully Implemented Compulsory Settlement
}

Marjeta Zorin Bukovšek

PhD Student at the Faculty of Economics and Business, University of Maribor, Slovenia

marjeta.zorin@siol.net

\section{Borut Bratina}

Faculty of Economics and Business, University of Maribor, Slovenia borut.bratina@um.si

\section{Polona Tominc}

Faculty of Economics and Business, University of Maribor, Slovenia polona.tominc@um.si

\begin{abstract}
In Slovenia, many companies try to avoid bankruptcy with the introduction of a compulsory settlement procedure, but only a handful of companies successfully complete the compulsory settlement in the sense of a final repayment of creditors in accordance with the adopted financial restructuring plan. The article identified the factors affecting the confirmation of a compulsory settlement as well as the factors affecting the final repayment of creditors and, thus, permanently eliminated the causes of insolvency. The factors were divided into internal and external, whereby the impact of factors on a successfully completed compulsory settlement was verified using quantitative and qualitative research methods.
\end{abstract}

Keywords: compulsory settlement, insolvency, financial restructuring plan, business restructuring, ownership restructuring

\section{Introduction}

A compulsory settlement procedure typically begins after the occurrence of insolvency of the debtor and allows the prevention of bankruptcy with the reorganization of the debtor's assets and the overall reduction of the claims incurred up to the beginning of the procedure. From a legal point of view, compulsory settlement is a contract concluded between the debtor and creditors before the court, which reduces the claims of the debtors and/or suspends their payment (Šinkovec \& Škerget, 1999, p. 17). The purpose of a compulsory settlement is to annul insolvency - that is, the economic situation as a result of which a bankruptcy proceeding may be initiated against the debtor. Under Article 136 of ZFPPIPP (2014), the compulsory settlement procedure is carried out to implement financial restructuring of the debtor's undertaking, which ensures that debtor's partners can only retain such a portion of the debtor's share capital that corresponds to the value of the remaining assets of the debtor that would be given to them if a bankruptcy proceeding was initiated against the debtor. At the same time, it is necessary to ensure more favorable terms of payment of the claims to creditors as 
if a bankruptcy proceeding was initiated against the debtor; in addition, the sense of a compulsory settlement procedure is the continued operation of the debtor's undertaking or the profitable part of this undertaking. Compulsory settlement is accepted and confirmed by the creditors, but is only successfully implemented when the debtor repays all the creditors in accordance with the financial restructuring plan.

Numerous factors affect the compulsory settlement procedure; therefore, we tried to identify factors of key importance, which we divided into internal and external factors. External factors are independent from the company (the management has no direct impact on them) whereas internal factors are those that arise in the company (the management has a direct impact on them).

The purpose of this article is complex in that it aims to provide an (i) analysis and definition of the factors affecting the successful implementation of the compulsory settlement; (ii) a formulation of recommendations for the company to successfully implement the compulsory settlement, and (iii) a formulation of recommendations for the holders of the economic policy in the field of support for the successful restructuring of the companies.

\section{Literature Overview and Hypotheses}

External factors. External factors include macroeconomic factors, such as fluctuations of the gross domestic product, interest rates, inflation, and other performance categories or criteria of a particular national economy. Manavald (2010) defined a close correlation between the decline of GDP and the increased number of insolvency proceedings in the case of Estonia; similar conclusions were also reached by Halim, Mohd Daud, Rizal Mazlan, and Marzuki (2008), whereby the latter analyzed corporate insolvency and fluctuations of GDP in the case of Malaysia. Gaffeo and Santoro (2009), Archambault and Laverdière (2005), and Moravec (2010) confirmed in their studies the impact of the fluctuations of GDP as well as interest rates and inflation on the number of initiated insolvency proceedings. The link between the fluctuations of GDP and the number of insolvency proceedings is in the form of a negative correlation between the aforementioned variables.

Fluctuations of GDP are closely associated with the changes in the amount of the interest rate and inflation. The review of the literature revealed that authors put the interest rate in the foreground as a key factor for the changing number of initiated bankruptcy proceedings and compulsory settlements. Sharabany (2004) statistically confirmed that the number of bankruptcy proceedings increases with the rise of the nominal interest rate. Yet the rise in nominal interest rate does not affect the financial stability of major export companies as they are not limited to the acquisition of capital on the domestic market. Statistical analysis results also showed that the number of bankrupt companies grows with unexpected inflation and positive changes in the nominal and the real interest rate. As a general rule, there is a positive correlation between the fluctuations of the interest rate and the number of initiated insolvency proceedings, but it must be pointed out that the positive correlation is stronger if several years of delay are taken into consideration. This means that the consequences of an increased interest rate in the economy are only visible after a few years. In the case of the Czech Republic, Moravec (2010, p. 6) established a strong positive correlation between the interest rate and the number of insolvency proceedings by a delay of three years. Kaplin et al. (2009, p. 11) also established a positive correlation between the fluctuations of the short-term interest rate and the degree of non-payment by companies. A positive correlation is visible in the long term, while in the short term a negative correlation is evident among the aforementioned variables.

Important external factors in successful financial restructuring of a company are also insolvency legislation (Armour, 2003; Ayotte \& Skeel, 2009; Pindado, Rodrigues, \& de la Torre, 2008; Succurro, 2008; Tarantino, 2009) and the role of the banking system (Brunner \& Krahnen, 2001; Davydenko \& Franks, 2006; Franks \& Sussman, 2003; Huang \& Huang, 2009; Levine, 1998; Senbet \& Seward, 1995).

Internal factors. Internal factors are factors that apply to an individual company and can be influenced by the management of the company. In the event of a vote for confirmation of a compulsory settlement, the amount of the repayment and the period in which the creditors would be repaid are very important factors. The higher the percentage of repayment offered by the debtor to the creditors and the shorter the deadline for the execution of the payment, the greater the chances are that the creditors will agree with the proposal for compulsory settlement. There is an existing belief that a high repayment of creditors should be possible over a longer period, while lower repayments should be feasible in a shorter period.

Internal factors also include the size of the company. Larger companies may have a better negotiating position, given their ability to persuade creditors on the soundness of a compulsory settlement (Constantini, 2009; Ohlson, 1980; Sengupta \& Faccio, 2011). On the contrary, Sun (2010) demonstrated a positive correlation between the size of the company and the chance of bankruptcy, whereby it is emphasized that a positive correlation could be attributed to the fact that, when a financial crisis appears in a larger company, this reflects quite serious problems that had accumulated over the years 
and are therefore more difficult to solve than they would have been in smaller companies.

The research also revealed that the financial situation and the operation of the company before the compulsory settlement are also important internal factors. The starting point from which the company works to solve the crisis in the company is extremely important for the continued development of events, while the company's financial situation also influences the formation of a proposal for compulsory settlement. Financial indicators are an important tool in assessing the performance of companies and forecasting their potential insolvency (Back, Laitinen, Sere, \& Wezel, 1996; Branch \& Xu, 2008; Heine, 2000; Stanišić, Mizdraković, \& Knežević, 2013).

An agreement with the creditors is a factor that we believe is extremely important for the successful implementation of a compulsory settlement. In addition to an agreement with the creditors, the restructuring method of the liabilities of the debtor, which is enabled by the legislation, is important (i.e., the conversion of a creditor's claims in the equity of an insolvent company). A key element of any conversion of claims into equity is thus the balance sheet restructuring of a corporate debtor so that important creditors-usually mostly financial creditors (i.e., banks) — receive equity in a reorganized capital structure in return for a reduction of their claims toward the debtor. This restructuring method comes from the American economy, where the conversion method is well established (Baird, 1997; Fuller, 1940; Lubben, 2004). In Slovenia, the increase in share capital with in-kind contributions is governed by ZGD-1, while we only received the legal basis (in ZFPPIPP) to increase the share capital by substantial or new cash contributions without the consent of the shareholders within the framework of a compulsory settlement a few years ago (Plavšak, 2011, pp. 28-34). Clowry (2008) also offered some examples of European companies that have successfully gone through the process of reorganization using the conversion of debts.

We listed internal factors, which are more or less related to financial and ownership restructuring, but it is also necessary to point out the factor of the implementation of other measures of business restructuring. The methods of business restructuring eliminate the causes leading companies to insolvency and essential for the companies to operate successfully after a confirmed compulsory settlement (solvent in the short and long term; Dubrovski, 2004).

Given the fact that companies' decision-makers are people who do not always follow the principle of rationality, but often operate emotionally, the psychological aspect of crisismanagement in a company and the communication among stakeholders are extremely important factors in the successful completion of a compulsory settlement (Berk, Peterlin, \& Ribarič, 2005, pp. 39-48; Pearson \& Clair, 1998, pp. 4-6).

Based on the review of theoretical foundations, we defined the following hypotheses, which were verified in the research:

$\mathrm{H}_{1}$ : The fluctuations of macroeconomic indicators influence the number of confirmed compulsory settlements.

$\mathrm{H}_{1 \mathrm{a}}$ : A decline in economic growth influences the decreased number of confirmed compulsory settlements.

$\mathrm{H}_{1 \mathrm{~b}}$ : A decline in inflation influences the decreased number of confirmed compulsory settlements.

$\mathrm{H}_{1 \mathrm{c}}$ : A reduced interest rate influences the decreased number of confirmed compulsory settlements.

$\mathrm{H}_{2}$ : The proposed deadline to repay the creditors is affected by the amount of repayment, company size, and the amount of working capital (on the cut-off day before compulsory settlement).

$\mathrm{H}_{3}$ : Key features that distinguish companies for which compulsory settlement was confirmed and those for which compulsory settlement was not confirmed are the amount of working capital, the deadline for repayment of ordinary creditors proposed in the financial restructuring plan, and the amount of the proposed repayment.

$\mathrm{H}_{4}$ : The long-term rehabilitation of a company demands simultaneous financial, ownership, and business restructuring.

$\mathrm{H}_{4 \mathrm{a}}$ : For a successful final repayment of creditors from the compulsory settlement, in addition to an agreement with ordinary creditors, the debtor also has to reach an agreement with the secured creditors about the restructuring of their claims so that the debtor can achieve a sustainable debt (financial restructuring).

$\mathrm{H}_{4 \mathrm{~b}}$ : The conversion of debts in equity shares or the acquisition of management (under Articles 144, 199.a or 199.b) allows a successful final restructuring of a company.

$\mathrm{H}_{4 c}$ : Business restructuring in the context of the implementation of all measures referred to in the financial restructuring plan depends on the amount of working capital available to the company and is essential for the long-term rehabilitation of the company.

$\mathrm{H}_{5}$ : Good communication among the management of the company, creditors, the administrator, and other stakeholders 
of the company and the preparedness of all stakeholders of the company to rescue the insolvent company enable successful long-term rehabilitation.

\section{Research Methodology}

Hypotheses $\mathrm{H}_{1 \mathrm{a}}$ to $\mathrm{H}_{1 \mathrm{c}}$ were verified with a simple linear regression analysis. Hypothesis $\mathrm{H}_{2}$ was verified with a multiple regression analysis. One of the multivariate methods is also the discriminant analysis, which was used to examine the $\mathrm{H}_{3}$ hypothesis. The discriminant analysis was used to determine and explain the differences between a group of companies for which a compulsory settlement was confirmed and a group of companies for which the compulsory settlement was not confirmed and ended in bankruptcy.

When verifying hypotheses $\mathrm{H}_{1 \mathrm{a}}-\mathrm{H}_{1 \mathrm{c}}$, we used secondary data obtained from publicly available databases-namely, Surs, Ajpes, Umar, Eurostat, Bank of Slovenia, Ministry of Justice of the Republic of Slovenia, and others. In hypotheses $\mathrm{H}_{1 \mathrm{a}}-\mathrm{H}_{1 \mathrm{c}}$, the number of confirmed compulsory settlements appeared in the role of a dependent variable. The variable of the number of confirmed compulsory settlements is in the form of a time series, as it included companies in Slovenia according to individual consecutive years for which a compulsory settlement was initiated and also voted for. This variable refers to the 2001-2014 period, whereby the period can vary for some hypotheses (e.g., 2002-2014 or 2003-2014) due to the availability of data on independent variables. Data for the annual number of confirmed compulsory settlements were acquired from the annual publications of court statistics, which are published on the website of the Ministry of Justice of the Republic of Slovenia.

To test hypotheses $\mathrm{H}_{2}$ and $\mathrm{H}_{3}$, we used data that we gathered on our own from databases by Audit \& Co. (i.e., Družba za Revizijo in Svetovanje) and Zo-fing, d. o. o. (i.e., Svetovalno in Trgovsko Podjetje); we also used the database found on the website of Ajpes. The sampling method we used represents non-random sampling; 82 companies for which compulsory settlement was initiated were selected for the sample. The non-random sampling method was used because we randomly selected companies from the available data (there are no data available for the entire statistical set) for which compulsory settlement was initiated since 2008 and either completed with voting or stopped and changed to bankruptcy proceedings. Data on individual variables were obtained from the financial statements that are part of the financial restructuring plan, and they reported on the financial position and business operations of the debtor. In the selection of units for the sample, we focused on companies that had gone through a compulsory settlement between 2008 and 2013 because, in 2008, the new Financial Operations, Insolvency Proceedings and Compulsory Dissolution Act (ZFPPIPP) went into effect.

Hypotheses $\mathrm{H}_{4}$ and $\mathrm{H}_{5}$ were examined with a qualitative method, using a multiple holistic case study. Only a few companies successfully finished the compulsory settlement, and some repaid their creditors only to later go bankrupt. Kotnik (2014) also pointed out the extremely low percentage of successfully completed compulsory settlements. When verifying hypotheses $\mathrm{H}_{4}$ and $\mathrm{H}_{5}$, which refer to business operations after the confirmed compulsory settlement, we also used primary data in addition to secondary data, such as non-structured and in-depth interviews with the management of insolvent companies and the stakeholders of these companies as well as experts in the field of finance and law. At the same time, we also used an observation technique, such as with the discussions of creditor committees, communication between the debtor and creditors, and the functioning of the administrator in the compulsory settlement procedure. The sample included three companies that successfully completed the compulsory settlement procedure, meaning they repaid the creditors: Iskraemeco, d.d., Steklarna Rogaška, d.d., and KG-EKO, d.o.o. We analyzed the following in each case:

- causes of insolvency

- the proposed compulsory settlement offered by the debtor in the financial restructuring plan

- the business operation and the implementation of the measures written in BRP after the confirmed compulsory settlement

- the repayment of liabilities from the confirmed compulsory settlement, and the analysis of the financial situation after the completed compulsory settlement

Case studies of companies against which the compulsory settlement was finally confirmed, but not yet completed, were used for the additional verification of the hypotheses. These companies had undergone the compulsory settlement procedure a few years earlier, but the deadlines to repay the creditors had not yet expired. We analyzed the following companies: LIV Kolesa, d.o.o., Beti tekstilna industrija, d.d., and Semenarna Ljubljana, d.d.

\section{Research Results}

In the research, we analyzed the macroeconomic factors in connection with the changing number of confirmed compulsory settlements. In the linear regression analysis for the example of hypothesis $\mathrm{H}_{1 \mathrm{a}}$, we came to the following conclusions. The correlation coefficient $\mathrm{R}$ shows a strong linear relationship between GDP and the number of confirmed 
compulsory settlements (Table 1 ). The coefficient of determination shows that $81.6 \%$ of the variation of the dependent variable was explained by the variation of the independent variable. The variables are in the form of a time series, so we checked the presence of autocorrelation between residuals using the Durbin-Watson test. We discovered no autocorrelation between the residuals of the sample.

Based on the F-test, we established that the obtained regression function was of good quality because the null hypothesis about the coefficient of determination being zero can be turned down at a significance level lower than 0.05 (Table 2).
The negative sign before the regression coefficient indicates that, if GDP increases one unit, confirmed compulsory settlements decrease by 0.008 unit, which means that the set hypothesis $\mathrm{H}_{1 \mathrm{a}}$ has to be rejected (Table 3 ). When setting up hypothesis $\mathrm{H}_{1 \mathrm{a}}$, we derived it from a practical point of viewnamely, that the uncertain economic conditions further complicated the survival of the companies during the compulsory settlement procedure, causing many compulsory settlements to fail and end in bankruptcy. At the same time, the creditors were quite careful when confirming compulsory settlement proposals, which were too optimistic given the economic situation. A statistical analysis showed the opposite, which can be attributed to the overall increase in insolvency proceedings

Table 1. Description of the Model, Correlation Coefficient, Coefficient of Determination, and Durbin-Watson Test

\begin{tabular}{|c|c|c|c|c|c|}
\hline \multicolumn{6}{|c|}{ Model summaryb } \\
\hline Model & & R Square & Adjusted R Square & $\begin{array}{l}\text { Std. Error of the } \\
\text { Estimate }\end{array}$ & Durbin-Watson \\
\hline 1 & $0.903^{a}$ & 0.816 & 0.801 & 9.319 & 1.518 \\
\hline
\end{tabular}

Note: a. Predictors: (Constant), gross domestic product (per resident in euro, current prices and prices according to the current exchange rate)

b. Dependent variable: confirmed compulsory settlements

Source: Authors' calculations, extracted from SPSS

Table 2. Analysis of Variance and the F-test

\begin{tabular}{|c|c|c|c|c|c|c|}
\hline \multicolumn{7}{|c|}{ ANOVA $^{a}$} \\
\hline Model & & Sum of Squares & df & Mean Square & $\mathrm{F}$ & Sig. \\
\hline \multirow{3}{*}{1} & Regression & $4,627.981$ & 1 & $4,627.981$ & 53.296 & $0.000^{\mathrm{b}}$ \\
\hline & Residual & $1,042.019$ & 12 & 86.835 & & \\
\hline & Total & $5,670.000$ & 13 & & & \\
\hline
\end{tabular}

Note: a. Dependent variable: confirmed compulsory settlements

b. Predictors: (Constant), gross domestic product (per resident in euro, current prices and prices according to the current exchange rate)

Source: Authors’ calculations, extracted from SPSS

Table 3. Regression Coefficient Values and the t-test

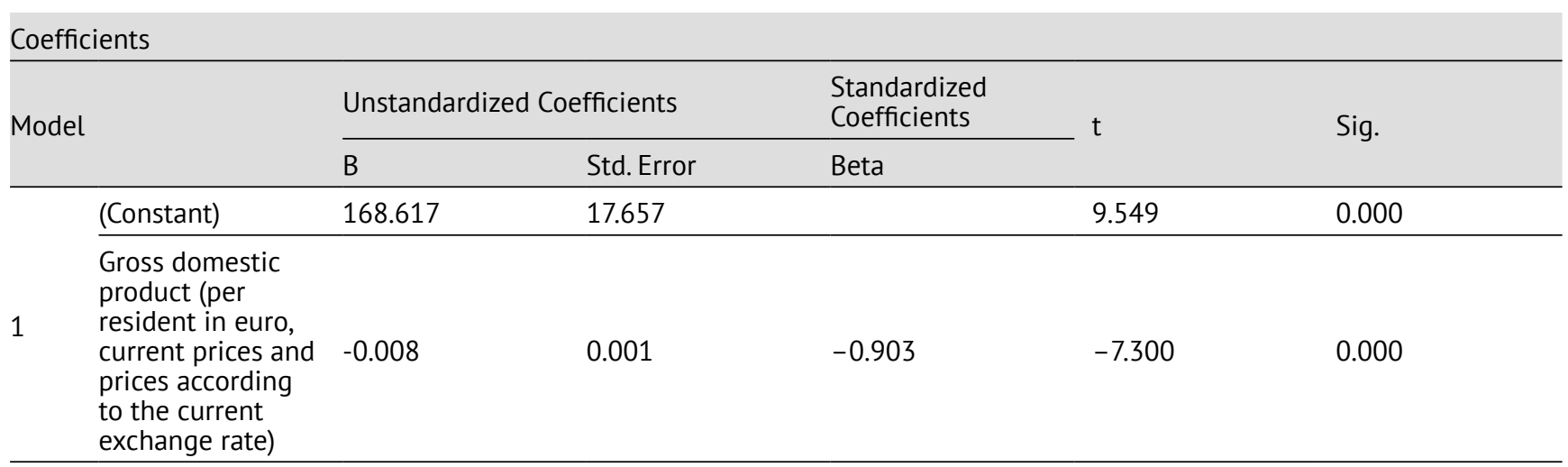

Note: Dependent variable: confirmed compulsory settlements

Source: Authors' calculations, extracted from SPSS 
during the economic crisis and consequently a greater number of confirmed compulsory settlements.

Hypothesis $\mathrm{H}_{1 \mathrm{a}}$ was rejected, but we can say that changes in GDP affected the changes in the number of confirmed compulsory settlements.

The correlation coefficient in the case of hypothesis $H_{1 b}$ showed a medium strong correlation between changes in inflation and the number of confirmed compulsory settlements (Table 4). The assumption that the dependent variable residuals were uncorrelated cannot be confirmed as the value of the Durbin-Watson test fell under the lower reference limit of 1.5. Autocorrelation occurred more often in data in the form of a time series due to the inertia. The presence of autocorrelation reduced the reliability of the obtained results.

From the point of view of the analysis of variance and the calculated F-test, the regression model was of good quality because the null hypothesis $\left(H_{0}: r_{x y}^{2}=0\right)$ could be rejected at a significance level lower than 0.05 (Table 5).

The $t$-test demonstrated that the calculated regression coefficient was statistically significantly different from zero, as the calculated significance level was lower than 0.05 (Table 6). The sign of the calculated regression coefficient was positive, indicating a positive correlation between the change in inflation and the number of confirmed compulsory settlements. Hypothesis $\mathrm{H}_{1 \mathrm{~b}}$ was not rejected.

From the theoretical point of view, a reduction in the rate of inflation encourages economic activity and, thus, GDP growth. However, the time delay should also be mentioned in the change of inflation. This delay could be particularly felt in the recent economic crisis, in which-despite the low inflation rate-there was no significant economic recovery, which was also reflected in the lower number of confirmed

Table 4. Description of the Model, Correlation Coefficient, Coefficient of Determination, and Durbin-Watson Test

\begin{tabular}{|c|c|c|c|c|c|}
\hline \multicolumn{6}{|c|}{ Model summary ${ }^{b}$} \\
\hline \multicolumn{2}{|c|}{ Model R } & R Square & Adjusted R Square & $\begin{array}{l}\text { Std. Error of the } \\
\text { Estimate }\end{array}$ & Durbin-Watson \\
\hline 1 & $0.716^{a}$ & 0.512 & 0.468 & 14.539 & 0.717 \\
\hline
\end{tabular}

Note: a. Predictors: (Constant), inflation, annual

b. Dependent variable: confirmed compulsory settlements

Source: Authors’ calculations, extracted from SPSS

Table 5. Analysis of Variance and the F-test

\begin{tabular}{|c|c|c|c|c|c|c|}
\hline \multicolumn{7}{|c|}{ ANOVA $^{a}$} \\
\hline Model & & Sum of Squares & df & Mean Square & $F$ & Sig. \\
\hline \multirow{3}{*}{1} & Regression & $2,439.128$ & 1 & $2,439.128$ & 11.539 & $0.006^{b}$ \\
\hline & Residual & $2,325.180$ & 11 & 211.380 & & \\
\hline & Total & $4,764.308$ & 12 & & & \\
\hline
\end{tabular}

Note: a. Dependent variable: confirmed compulsory settlements

b. Predictors: (Constant), inflation, annual

Source: Authors’ calculations, extracted from SPSS

Table 6. Regression Coefficient Values and the t-test

\begin{tabular}{|c|c|c|c|c|c|c|}
\hline \multicolumn{7}{|c|}{ Coefficients } \\
\hline \multirow{2}{*}{\multicolumn{2}{|c|}{ Model }} & \multicolumn{2}{|c|}{ Unstandardized Coefficients } & \multirow{2}{*}{$\begin{array}{l}\text { Standardized } \\
\text { Coefficients } \\
\text { Beta }\end{array}$} & \multirow[t]{2}{*}{$t$} & \multirow[t]{2}{*}{ Sig. } \\
\hline & & B & Std. Error & & & \\
\hline \multirow{2}{*}{1} & (Constant) & 16.671 & 7.654 & & 2.178 & 0.052 \\
\hline & Inflation, annual & 6.973 & 2.053 & 0.716 & 3.397 & 0.006 \\
\hline
\end{tabular}

Note: Dependent variable: confirmed compulsory settlements

Source: Authors' calculations, extracted from SPSS 
compulsory settlements. The recent economic crisis showed that changes in inflation and interest rates did not cause an immediate impact on the economic activity, but other important factors still emerged-mainly political events in the country and around the world.

The regression analysis in the case of hypothesis $\mathrm{H}_{1 \mathrm{C}}$ revealed a medium strong relationship between the change in interest rate and the number of confirmed compulsory statements (Table 7). As with hypothesis $\mathrm{H}_{1 \mathrm{~b}}$, the Durbin-Watson statistics did not allow us to confirm the assumption about the residuals being uncorrelated.

The regression model was of good quality because the null hypothesis could be rejected at the significance level lower than 0.05 (Table 8).
The regression coefficient was statistically significantly different from zero at the significance rate lower than 0.05 (Table 9). The sign of the mentioned regression coefficient was positive, indicating that an increase in the interest rate effected an increase in confirmed compulsory settlements. Thus, hypothesis $\mathrm{H}_{1 \mathrm{C}}$ was not rejected.

Changes in the interest rate were thus indicated in the changes of GDP, but it was necessary to consider several years of delay-the same as in the event of changes in inflation. Although interest rates have decreased in recent years, no detectable larger scope of loans to companies and, thus, increases in economic activity could be identified in Slovenia. Banks have become extremely careful when granting loans to companies because of previous negative

Table 7. Description of the Model, Correlation Coefficient, Coefficient of Determination, and Durbin-Watson Test

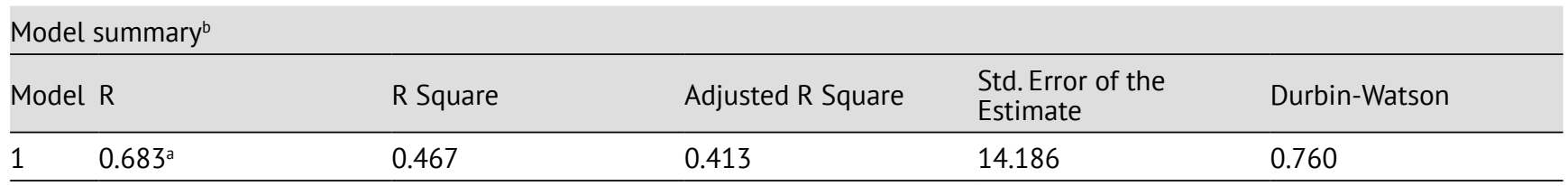

Note: a. Predictors: (Constant), interest rate for loans of up to 1 million euro, variable and fixed interest rate of up to 1 year (in \%)

b. Dependent Variable: confirmed compulsory settlements

Source: Authors' calculations, extracted from SPSS

Table 8. Analysis of Variance and the F-test

\begin{tabular}{lllllll}
\multicolumn{1}{ll}{ ANOVA $^{\mathrm{a}}$} \\
\multicolumn{1}{l}{ Model } & Sum of Squares & $\mathrm{df}$ & Mean Square & $\mathrm{F}$ & Sig. \\
\hline \multirow{3}{*}{1} & Regression & $1,761.759$ & 1 & $1,761.759$ & 8.754 & $0.014^{\mathrm{b}}$ \\
\cline { 2 - 8 } & Residual & $2,012.491$ & 10 & 201.249 & & \\
\cline { 2 - 8 } & Total & $3,774.250$ & 11 & & & \\
\hline
\end{tabular}

Note: a. Dependent Variable: confirmed compulsory settlements

b. Predictors: (Constant), interest rate for loans of up to 1 million euro, variable and fixed interest rate of up to 1 year (in \%)

Source: Authors' calculations, extracted from SPSS

Table 9. Regression Coefficient Values and the t-test

\begin{tabular}{|c|c|c|c|c|c|c|}
\hline \multicolumn{7}{|c|}{ Coefficients } \\
\hline \multirow[t]{2}{*}{ Model } & & \multicolumn{2}{|c|}{ Unstandardized Coefficients } & \multirow{2}{*}{$\begin{array}{l}\text { Standardized } \\
\text { Coefficients } \\
\text { Beta } \\
\end{array}$} & \multirow[t]{2}{*}{$\mathrm{t}$} & \multirow{2}{*}{ Sig. } \\
\hline & & B & Std. Error & & & \\
\hline & (Constant) & -33.673 & 23.985 & & -1.404 & 0.191 \\
\hline 1 & $\begin{array}{l}\text { Interest rate for } \\
\text { loans of up to } \\
1 \text { million euro, } \\
\text { variable and fixed } \\
\text { interest rate of up } \\
\text { to } 1 \text { year (in \%) }\end{array}$ & 11.164 & 3.773 & 0.683 & 2.959 & 0.014 \\
\hline
\end{tabular}

Note: Dependent Variable: confirmed compulsory settlements

Source: Authors' calculations, extracted from SPSS 
experiences. Stricter banking terms for the operation of companies have also hindered the operation of companies during compulsory settlements, causing many to declare bankruptcy. The decrease in interest rates resulted in a reduction in the number of confirmed compulsory settlements.

When checking hypothesis $\mathrm{H}_{2}$, we used the multiple regression analysis, which revealed medium strong dependencies between the dependent and independent variables (Table 10). The multiple determination coefficient of determination was low and showed that only $24 \%$ of the total variance could be explained by the variability of independent variables. The Durbin-Watson test indicated no autocorrelation between the residuals of the sample because the value of the mentioned statistics was within the limits $(1.5<d<2.5)$.
The significance level in the F-test was lower than the reference significance level of 0.05 , indicating that the coefficient of determination was statistically different from zero and that the multiple regression function was of good quality (Table 11).

$T$-tests for individual regression coefficients demonstrated that the regression coefficients for the variables of company size and amount of repayment were statistically different from zero whereas, regarding working capital, we could not reject the null hypothesis that the regression coefficient was different from zero (Table 12). The larger the company and the higher the proposed repayment, the longer the deadline for the repayment of creditors in accordance with the proposal described in the financial restructuring plan. For

Table 10. Description of the Model, Multiple Correlation Coefficient, Multiple Coefficient of Determination, and the Durbin-Watson Test

\begin{tabular}{|c|c|c|c|c|}
\hline \multicolumn{5}{|c|}{ Model summary ${ }^{b}$} \\
\hline Model R & R Square & Adjusted R Square & $\begin{array}{l}\text { Std. Error of the } \\
\text { Estimate }\end{array}$ & Durbin-Watson \\
\hline $0.518^{\mathrm{a}}$ & 0.268 & 0.240 & 0.16407 & 1.957 \\
\hline
\end{tabular}

Note: $\quad$ a. Predictors: (Constant), logsize, loglevel, working capital/net revenue from sales

b. Dependent variable: logdeadline

Source: Authors’ calculations, extracted from SPSS

Table 11. Analysis of Variance and the F-test

\begin{tabular}{lllllll}
\multicolumn{1}{l}{ ANOVA $^{\mathrm{a}}$} & \multicolumn{1}{l}{} \\
\hline \multicolumn{1}{l}{ Model } & Sum of Squares & $\mathrm{df}$ & Mean Square & $\mathrm{F}$ & Sig. \\
\hline \multirow{3}{*}{1} & Regression & 0.769 & 3 & 0.256 & 9.527 & $0.000^{\text {b }}$ \\
\cline { 2 - 7 } & Residual & 2.100 & 78 & 0.027 & & \\
\cline { 2 - 7 } & Total & 2.869 & 81 & & & \\
\hline
\end{tabular}

Note: $\quad$ a. Dependent variable: logdeadline

b. Predictors: (Constant), logsize, loglevel, working capital/net revenue from sales

Source: Authors' calculations, extracted from SPSS

Table 12. Regression Coefficient Values, t-tests, and Multicollinearity Test (VIF)

\begin{tabular}{|c|c|c|c|c|c|c|c|c|}
\hline \multicolumn{9}{|c|}{ Coefficients } \\
\hline \multirow{2}{*}{ Model } & & \multicolumn{2}{|c|}{ Unstandardized Coefficients } & \multirow{2}{*}{$\begin{array}{l}\text { Standardized } \\
\text { Coefficients } \\
\text { Beta } \\
\end{array}$} & \multirow[t]{2}{*}{$\mathrm{t}$} & \multirow{2}{*}{ Sig. } & \multicolumn{2}{|c|}{ Collinearity statistics } \\
\hline & & B & Std. Error & & & & Tolerance & VIF \\
\hline \multirow{4}{*}{1} & (Constant) & 0.384 & 0.189 & & -2.031 & 0.046 & & \\
\hline & $\begin{array}{l}\text { Working capital/ } \\
\text { net revenue from } \\
\text { sales }\end{array}$ & 4.741E-006 & 0.000 & 0.055 & 0.533 & 0.596 & 0.878 & 1.140 \\
\hline & loglevel & 0.256 & 0.075 & 0.352 & 3.409 & 0.001 & 0.879 & 1.138 \\
\hline & logsize & 0.078 & 0.027 & 0.300 & 2.860 & 0.005 & 0.850 & 1.176 \\
\hline
\end{tabular}

Note: Dependent variable: logdeadline

Source: Authors' calculations, extracted from SPSS 
the variable of working capital, we could not confirm that it affected the length of the deadline to repay the creditors, as proposed by the debtor. The presence of multicollinearity was checked with the factor of variance inflation, whereas the factor values were very low (close to 1 ), meaning that the independent variables were not strongly correlated among each other and the regression model was, thus, stable.

Hypothesis $\mathrm{H}_{2}$ could be partially accepted, because we were unable to statistically confirm the effect of the independent variable of working capital on the dependent variable during the period for the repayment of creditors.

$\mathrm{H}_{3}$ was checked with the discriminant analysis for two groups. The eigenvalue revealed that the obtained discriminant function did not allow for a good distinction between the group of companies with confirmed compulsory settlements and the group of companies with unconfirmed compulsory settlements (Table 13). The low eigenvalue indicated that the calculated discriminant function only captured $7.4 \%$ of the total variance of measured variables. The value of the canonical correlation also suggested that only $26.3 \%$ of the variation between groups could be explained with the discriminant function.

Poor differentiation between the groups was also indicated by the high Wilks' lambda value (Table 14). The high significance level in the chi-square test speaks in favor of the null hypothesis about the equality of average values of the discriminant function in groups, meaning that hypothesis $\mathrm{H}_{3}$ was rejected because the discriminant function did not allow for a good distinction between the two groups.

Table 15 summarizes the standardized discriminant function coefficients, showing that-in the distinction between groups - the most important variable was the size of the company, followed by the capital coverage of long-term assets, on the basis of which the level of capital prior to filing a compulsory settlement and the level of working capital on the cut-off day before filing the proposal for a compulsory settlement were indicated (Table 15).

Hypothesis $\mathrm{H}_{3}$ was rejected, because the calculated discriminant function was not of good quality. The reasons for

Table 13. Eigenvalues

\begin{tabular}{lllll} 
Eigenvalues & & & \\
\hline Function & Eigenvalue & \% of variance & Cumulative \% & Canonical correlation \\
\hline 1 & 0.074 & 100.0 & 100.0 & 0.263 \\
\hline
\end{tabular}

Note: First, 1 canonical discriminant function was used in the analysis.

Source: Authors' calculations, extracted from SPSS

Table 14. Wilks' Lambda and Chi-square Test

\begin{tabular}{lllll} 
Wilks' lambda & & & \\
\hline Test of function(s) & Wilks' lambda & Chi-Square & df & Sig. \\
\hline 1 & 0.931 & 5.534 & 5 & 0.354 \\
\hline
\end{tabular}

Source: Authors' calculations, extracted from SPSS

Table 15. Standardized Discriminant Function Coefficients

Standardized Canonical Discriminant Function Coefficients

\begin{tabular}{ll}
\hline & Function \\
\hline Working capital/net revenue from sales & 1 \\
\hline coefficient of coverage of long-term assets = capital/long-term assets & 0.325 \\
\hline logsize & 0.663 \\
\hline loglevel & -0.762 \\
\hline logdeadline & 0.158 \\
\hline
\end{tabular}

Source: Authors' calculations, extracted from SPSS 
the poor quality of the calculated discriminant function can be attributed to the violation of the basic assumptions on which the discriminant analysis is based. These violations are (Marinšek, 2015, p. 95):

- the units in each group are not selected at random because there are no data available for the entire statistical set;

- not all independent variables are distributed normally; and

- $\quad$ there is multicollinearity between independent variables.

The discriminant function did not allow for a good distinction between the groups, which resulted from the fact that the distinction between companies with confirmed compulsory settlement and the companies with unconfirmed compulsory settlement was also affected by factors not included in the discriminant analysis. These factors of agreement mostly occurred with the creditors seeking to restructure their claims and communicate with stakeholders and the psychological aspect of solving the crisis in the company. Due to the difficult measurability of these factors, the latter had to be left out of the implementation of the discriminant analysis, and their effects on the course of the procedure of compulsory settlement were discussed when checking the hypotheses with the quality research methods.

The qualitative research method of a case study was used to analyze six Slovenian companies that have successfully undergone the compulsory settlement procedure. Among them, three companies also finally repaid their creditors in accordance with the proposed compulsory settlement. An analysis of the focus group of companies showed that the successful implementation of a compulsory settlement requires an agreement with the secured creditors on the restructuring of their claims, conversion of creditors' claims in equity shares of the company, business restructuring, and communication among all stakeholders of the company. Case studies have shown that all companies for which banks acted as secured creditors entered into an agreement with these banks on the restructuring of their claims within the meaning of a moratorium on the repayment of the principal and control of the amount of the annual interest rate. Ownership restructuring was also carried out in the analyzed companies, either with the conversion of debts into the share capital of the company during the compulsory settlement procedure and/or recapitalization after the compulsory settlement. At the same time, business restructuring measures were implemented in all companies and are still being implemented, thereby ensuring that the company releases its potential for further development while eliminating the causes of insolvency in the long term. Hypothesis $\mathrm{H}_{4}$ was confirmed.

Given that companies' decision-makers do not always follow the principle of rationality, but often operate emotionally, the psychological aspect of crisis management in the company and the communication among their stakeholders are extremely important factors in the successful completion of the compulsory settlement. During the compulsory settlement procedure, numerous conflicts arose in all the analyzed companies, either between the management and the creditors or between the owners and the creditors or even among all the stakeholders. An important observation was that conflicts were promptly resolved with good communication, which enabled the successful implementation of the procedure. Hypothesis $\mathrm{H}_{5}$ was confirmed.

\section{Discussion}

Manavald (2010), Halim et al. (2008), Gaffeo and Santoro (2009), Archambault and Laverdière (2005), Moravec (2010), Sharabany (2004), Kaplin et al. (2009), and many other researchers have established a link between the change in the macroeconomic indicators and the number of insolvency procedures around the world. When checking the partial hypotheses $\mathrm{H}_{1 \mathrm{a}}-\mathrm{H}_{1 \mathrm{c}}$, we found that the macroeconomic indicators also affected the number of confirmed compulsory settlements. Despite the fact that hypothesis $\mathrm{H}_{1 \mathrm{a}}$ was rejected, the regression analysis indicated a strong link between changes in GDP and the number of compulsory settlements. The regression analysis of changes in GDP and the number of confirmed compulsory settlements for the 2001-2008 period also confirmed the negative correlation; thus, we can draw parallels between our findings and those of other authors. The regression analysis of changes in GDP and the number of confirmed compulsory settlements for the 2009-2014 period revealed that the economic crisis strongly affected the relationship between GDP and the number of confirmed compulsory settlements. In his book, Krugman (2012, p. 40) discussed the so-called Minsky moment that supports our findings. Krugman described the economic situation in which over-indebted subjects are forced to sell their property to pay their liabilities, which causes a fall in real estate prices and a sharp decline in market liquidity. At the same time, it indicates that the deleveraging cannot bring economic growth, but only deepens the crisis, which induces an increase in the number of bankrupt companies. Sun (2010), Constantini (2009), and Sengupta and Faccio (2011) established a link between the size of the company and the success of financial restructuring. Large companies are in a better negotiating position, so they may propose a longer period to repay their creditors. Regarding the level of working capital, the case is therefore exactly the opposite of that with the size of company and the amount of repayment: The more working capital that is available in the company during a compulsory settlement, the more likely the financial restructuring will be successful with a shorter period to repay the creditors. 
A qualitative analysis of selected companies revealed that several factors are essential for a confirmed compulsory settlement as well as the consequent final repayment of creditors and the long-term rehabilitation of the company-namely, an agreement between the debtor as well as the ordinary and secured creditors about the restructuring of their claims (financial restructuring), the conversion of claims into equity shares or the acquisition of management by the creditors (ownership restructuring), and the implementation of business restructuring measures. Our findings support the basic thesis established at the beginning of the research. Financial, ownership, and business restructuring efforts are crucial for long-term crisis resolution in the company and the resolution of insolvency. A successfully implemented compulsory settlement is only possible if the restructuring measures are carried out in the company on all three of these levels, otherwise it is very likely that the process will fail sooner or later.

\section{Conclusions}

Our research could form the basis for the formulation of recommendations for the management of companies and the formation of an appropriate economic policy in the field of support for successfully restructuring companies. By defining the basic factors for successfully rescuing companies through compulsory settlement, we also opened many new issues and ideas for further investigation. Our research showed that the psychological aspect of solving the crisis is an extremely important factor as well, but it is often ignored in economic sciences. Therefore, it would be reasonable to extend the research in the direction of an in-depth analysis of the psychological factors, which are important for solving crises in companies. In the next phase, each factor could be researched in more detail individually or in groups, depending on the type of restructuring. As rescuing a company in crisis requires interdisciplinarity, the compulsory settlement procedure could also be discussed from other aspects-for example, as a compulsory settlement procedure from the legislative aspect alone and, thus, as the constituting of proposals for improving the Slovenian insolvency legislation. It would also be very interesting to perform a more detailed analysis of the impact of the Slovenian banking system in solving a company crisis. Further research could also be performed in the direction of the annual collection of data on successfully executed, finished compulsory settlements. These data could later form the basis for the performance of statistical analyses, such as with a discriminant analysis, to help us analyze the key differences between companies that ended in bankruptcy and those that successfully restructured during the compulsory settlement process.

\section{References}

Archambault, R., \& Laverdière, D. (2005). A macroeconomic model for analysing and forecasting levels of business and consumer insolvency in Canada. Economic Information and Analysis Office of the Superintendent of Bankruptcy Industry Canada. Retrieved from http://www.ic.gc.ca/eic/site/bsf-osb.nsf/vwapj/macroeconomicmodelforanalysingandforecastinginsolvency.pdf/\$file/macroeconomicmodelforanalysingandforecastinginsolvency.pdf

Armour, J. (2003). Financing innovation: The role of insolvency law. Retrieved from http://citeseerx.ist.psu.edu/viewdoc/ summary?doi=10.1.1.196.260

Ayotte, K., \& Skeel Jr., D. A. (2009). Bankruptcy or bailouts? Journal of Corporation Law, 35(3), 469-498. Retrieved from http://papers.ssrn. com/sol3/papers.cfm?abstract_id=1362639 https://doi.org/10.2139/ssrn.1362639

Back, B., Laitinen, T., Sere, K., \& Wezel, M. (1996). Choosing bankruptcy predictors using discriminant analysis, logit analysis, and genetic algorithms. Turku Centre for Computer Science, 40. Retrieved from http://intes-group.narod.ru/books/choosing_predictors.pdf

Baird, D. G. (1997). The hidden virtues of chapter 11: an overview of the law and economics of financially distressed firms. Coase-Sandor Working Paper Series in Law and Economics (Working Paper No. 43). Retrieved from http://www.law.uchicago.edu/files/files/43. Baird_.Chapter11.pdf.

Berk, A., Peterlin, J., \& Ribarič, P. (2005). Obvladovanje tveganja: skrivnosti celovitega pristopa. Ljubljana: GV Založba.

Branch, B., \& Xu, M. (2008). The power of Z-score to predict the post-bankruptcy performance. Retrieved from http://www.fma.org/Texas/ Papers/ThePowerofZScoretoPredictthePostbankruptcyPerformance2008.pdf

Brunner, A., \& Pieter Krahnen, J. (2001). Corporate debt restructuring: Evidence on lending coordination in financial distress. Financial Economics (Discussion Paper No. 3030). Retrieved from http://papers.ssrn.com/sol3/papers.cfm?abstract_id=290388

Clowry, K. (2008). Debt-for-equity swaps. Globe Law and Business, 27-58. Retrieved from http://www.globelawandbusiness.com/rw/ sample.pdf

Constantini, J. A. (2009). Effects of bankruptcy procedures on firm restructuring: Evidence from Italy (Draft Working Paper). Retrieved from http://www.insead.edu/facultyresearch/faculty/personal/jcostantini/research/documents/james_costantini_bankruptcy_italy.pdf

Davydenko, S. A., \& Franks, J. R. (2006). Do bankruptcy codes matter? A study of defaults in France, Germany and the UK (Finance Working Paper No. 89/2005). Retrieved from http://papers.ssrn.com/sol3/papers.cfm?Abstract_id=647861

Dubrovski, D. (2004). Krizni management in prenova podjetja. Koper: Fakulteta za management Koper. 
Marjeta Zorin Bukovšek, Borut Bratina, Polona Tominc: Factors of a Successfully Implemented Compulsory Settlement

Franks, J., \& Sussman, O. (2003). Financial distress and bank restructuring of small to medium size UK companies. Review of Finance, 9(1), 65-96. Retrieved from http://citeseerx.ist.psu.edu/viewdoc/download?Down=10.1.1.319.3964\&Rep=rep1\&type=PDF https:// doi.org/10.1007/s10679-005-2988-8

Fuller, W. (1940). The background and techniques of equity and bankruptcy railroad reorganizations-survey. Law and Contemporary Problems, 7(3), 377-392. Retrieved from http://scholarship.law.duke.edu/cgi/viewcontent.cgi?Article=2026\&context=LCP https:// doi.org/10.2307/1189700

Gaffeo, E., \& Santoro E. (2009). Business failures, macroeconomic risk and the effect of recessions on long-run growth: a panel cointegration approach. Journal of Economics and Business, 61(6), 435-452. Retrieved from http://www.econ.ku.dk/esantoro/images/ bankruptcy_sg.pdf https://doi.org/10.1016/j.jeconbus.2009.05.001

Halim, A., Mohd Daud, S. N., Rizal Mazlan, A., \& Marzuki, A. (2008). Macroeconomic determinants of corporate failures in Malaysia. International Journal of Business and Management, 3(3), 3-10. Retrieved from http://www.ccsenet.org/journal/index.php/ijbm/article/view/1621

Heine, M. L. (2000). Predicting financial distress of companies: Revisiting the Z-score and ZETA models. Adapted and updated from E. Altman, "Financial ratios, discriminant analysis and the prediction of corporate bankruptcy." Journal of Finance, September. Retrieved from http://pages.stern.nyu.edu/ ealtman/predfncldistr.pdf

Huang, J-C., \& Huang, C.-S. (2009). Bank relationships and firm private debt restructuring: a duration analysis. Banks and Bank Systems, 4(2), 38-47. Retrieved from http://businessperspectives.org/journals_free/bbs/2009/bbs_en_2009_2_huang.pdf

Kaplin, A., Levy, A., Qu, S., Wang, D., Wang, Y., \& Zhang, J. (2009). The relationship between default risk and interest rates: and empirical study. Moody's Analytics, October. Retrieved from http://www.moodysanalytics.com/ /media/Insight/Quantitative-Research/Portfolio-Modeling/09-10-02-Default-and-Interest-Rates.ashx

Kotnik, T. (2014). Polomije prisilnih poravnav. Finance, 70. Retrieved from http://www.finance.si/8800163

Krugman, P. (2012). Ustavimo to krizo takoj!. Ljubljana: Modrijan.

Levine, R. (1998). The legal environment, banks, and long-run economic growth. Journal of Money, Credit and Banking, 3(3), $596-613$. Retrieved from http://papers.ssrn.com/sol3/papers.cfm?Abstract_id=88888 https://doi.org/10.2307/2601259

Lubben, S.J. (2004). Out of the past: Railroads \& sovereign debt restructuring. Georgetown Journal of International Law (Draft for Presentation at Georgetown Symposium on sovereign debt restructuring). Retrieved from http://papers.ssrn.com/sol3/papers.cfm?Abstract_id=506122

Manavald, P. (2010). Economic crisis and the effectiveness of insolvency regulation. Juridica International, 17, 207-216. Retrieved from http://www.juridicainternational.eu/public/pdf/ji_2010_1_207.pdf

Marinšek, D. (2015). Multivariatna analiza: Zbirka rešenih primerov s komentarji. Ljubljana: Ekonomska fakulteta v Ljubljani, Založništvo.

Moravec, T. (2010). The bankruptcy in the Czech Republic-influence of macroeconomic variables. Retrieved from http://www.slu.cz/su/opf/ cz/informace/acta-academica-karviniensia/casopisy-aak/aak-rocnik-2013/docs-3-2013/Moravec.pdf

Ohlson, J. A. (1980). Financial ratios and the probabilistic prediction of bankruptcy. Journal of Accounting Research, 18(1), $109-131$. Retrieved from http://www.jstor.org/stable/2490395?seq=1\#page_scan_tab_contents https://doi.org/10.2307/2490395

Pearson,C.M., \& Clair,J.A.(1998). Reframing crisis management.InA.Boin (Ed.), Crisis management(Vol.II).London:Sage. Retrieved from http:// citeseerx.ist.psu.edu/viewdoc/download;jsessionid=DDCD3D04A2D63806FBBAAA82818B5778?doi=10.1.1.460.7005\&rep=rep1\&type=pdf https://doi.org/10.5465/amr.1998.192960

Pindado, J., Rodrigues, L., \& de la Torre, C. (2008). How do insolvency codes affect a firm's investment? International Review of Law and Economics, 28(4), 227-238. Retrieved from http://xiforofinanzas.ua.es/trabajos/1056.pdf https://doi.org/10.1016/j.irle.2008.08.001

Plavšak, N. (2011). Odločanje upnikov o spremembi osnovnega kapitala v postopku prisilne poravnave. Aktualna vprašanja insolvenčnega prava: 3. Strokovno srečanje, Hotel Golf, Bled, 1. in 2. December 2011. Ljubljana: GV Založba.

Senbet, L. W., \& Seward,J. K. (1995). Financial distress, bankruptcy and reorganization. Handbooks in Operations Research and Management Science, 9, 921-961. Retrieved from http://www.rhsmith.umd.edu/faculty/lsenbet/lemmas\%20papers/Financial\%20Distress,\%20 Bankruptcy\%20and\%20Reorganization.pdf https://doi.org/10.1016/S0927-0507(05)80072-6

Sengupta, R., \& Faccio, M. (2011). Corporate response to distress: Evidence from the Asian financial crisis. Federal Reserve Bank of St. Louis Review, 93(2), 127-154. Retrieved from http://citeseerx.ist.psu.edu/viewdoc/download?doi=10.1.1.204.6669\&rep=rep1\&type=pdf

Sharabany, R. (2004). Business failures and macroeconomic risk factors (Bank of Israel Discussion Paper No. 2004.06). Retrieved from http://www.bankisrael.gov.il/deptdata/mehkar/papers/dp0406e.pdf

Stanišić, N., Mizdraković, V., \& Knežević, G. (2013). Corporate bankruptcy prediction in the Republic of Serbia. Industrija, 40(4), $145-159$. Retrieved from http://papers.ssrn.com/sol3/papers.cfm?abstract_id=2368763

Succurro, M. (2008). Bankruptcy systems and economic performance across countries: some empirical evidence (Working Paper No. 200801). City: Universita della Calabria. Retrieved from http://econpapers.repec.org/paper/clbwpaper/200801.htm

Sun, L. (2010). The effects of client size and stress criteria on bankruptcy prediction models: An empirical analysis. Retrieved from https://www. google.si/search?q=The+Effects+of+Client+Size+and+Stress+Criteria+on+Bankruptcy+Prediction+Models:+An+Empirical+Analysis\&ie=utf-8\&oe=utf-8\&rls=org.mozilla:sl:official \&client=firefox-a\&channel=sb\&gws_rd=cr\&ei=JmNeU_G8CYHpywPIt4D4AO

Šinkovec, J., \& Škerget, D. (1999). Zakon o finančnem poslovanju z uvodnimi pojasnili in zakon o prisilni poravnavi, stečaju in likvidaciji s komentarjem. Ljubljana: Založniška hiša Primath.

Tarantino, E. (2009). Bankruptcy law and corporate investment decisions (TILEC Discussion Paper No. 2009-040). Retrieved from http:// arno.uvt.nl/show.cgi?fid=96696

ZFPPIPP. (2014). Financial operations, insolvency proceedings and compulsory dissolution act-official consolidated text-UPB8ZFPPIPP. Official Gazette of the RS, 13/2014. Retrieved from http://www.pisrs.si/Pis.web/pregledPredpisa?id=ZAKO4735 


\section{Authors}

Marjeta Zorin Bukovšek is a Ph.D. student at the Faculty of Economics and Business in Maribor. She graduated in 2009 with the help of her mentor, Professor Jani Bekő, Ph.D. In 2011, she successfully defended her master's thesis with Professor Borut Bratina, Ph.D. In her master's thesis, entitled Financial restructuring of a company with compulsory settlement, she familiarized herself with the field of commercial law, more specifically with insolvency proceedings. She works as an assistant director in the consulting company Zo-fing d.o.o., which mainly operates in the field of insolvency proceedings and crisis management.

Borut Bratina holds a Ph.D. in law and works as an associate professor at the Faculty of Economics and Business (Maribor University) in the Department of Business and Company Law. In 1980 he graduated from the Faculty of Law in Ljubljana and the School of Economics and Commerce in Maribor. He earned his M.Sc. in law after completing post-graduate studies at the Faculty of Law in Ljubljana in 1987 and his Ph.D. in law in 1997 from the Faculty of Law in Maribor.

Polona Tominc, PhD, is a professor in the Department of Quantitative Economic Analysis at the Faculty of Economics and Business, University of Maribor. Her research is focused on statistical methods in economics, especially in the field of entrepreneurship and gender differences. She teaches statistics, quantitative research methods and methodology within the entrepreneurial research. She has participated in more than 30 scientific and professional conferences, is the author of various chapters in books and articles in scientific and professional journals, and has published in Slovenia and abroad. She is participating in the DIANA network analyzing female entrepreneurship and is a team member of GEM Slovenia and the Slovenian entrepreneurship observatory research team.

\section{Analiza dejavnikov uspešno izvedene prisilne poravnave}

Izvleček

V Sloveniji se veliko podjetij poskuša izogniti stečaju z uvedbo postopka prisilne poravnave, vendar le peščica od njih prisilno poravnavo uspešno zaključi v smislu dokončnega poplačila upnikov s skladu s sprejetim načrtom finančnega prestrukturiranja. V članku smo opredelili tiste dejavnike, ki vplivajo na potrditev prisilne poravnave, in tudi tiste, ki vplivajo na dokončno poplačilo upnikov in s tem trajno odpravo vzrokov insolventnosti. Dejavnike smo razdelili na notranje in zunanje, njihov vpliv na uspešno dokončano prisilno poravnavo pa preverili s kvantitativnimi in kvalitativnimi metodami raziskovanja.

Ključne besede: prisilna poravnava, insolventnost, načrt finančnega prestrukturiranja, poslovno prestrukturiranje, lastniško prestrukturiranje 